\title{
Evolution of acoustic communication in crickets: phylogeny of Eneopterinae reveals an adaptive radiation involving high-frequency calling (Orthoptera, Grylloidea, Eneopteridae)
}

\author{
TONY ROBILLARD and LAURE DESUTTER-GRANDCOLAS \\ Muséum National d'Histoire Naturelle, Département Systématique et Evolution \\ USM601 MNHN \& FRE2695 CNRS, Case Postale 50 (Entomologie), 75231 Paris Cedex 05, France \\ Manuscript received on January 15, 2004; accepted for publication on February 5, 2004.
}

\begin{abstract}
Evolution of dominant frequencies in songs of Eneopterinae crickets was studied with respect to phylogeny. Two characters are optimized on the tree: the first describes the frequency resulting from the vibration of the harp (Fda), and the second is due to the vibration of other tegminal areas (Fdb). Fda was found to be relatively stable through the subfamily. Its low ancestral state is replaced by a high Fda only once, resulting in high-frequency calling in [Cardiodactylus (Lebinthus-Agnotecous)]. A high Fdb component is added to the low ancestral Fda in Eneoptera guyanensis, resulting in frequency modulation. The onset of high $\mathrm{Fd}$ in this first subclade is accompanied by a high cladogenesis rate, which supports a hypothesis of adaptive radiation for high frequencies. The effectiveness of high-frequency calling is discussed in relation to the species behavior ecology.
\end{abstract}

Key words: acoustic communication, adaptation, cladogenesis, Ensifera, evolutionary pattern, phylogeny.

\section{INTRODUCTION}

Crickets are well known among acoustic insects for the loud, pure-tone calls the males emit to attract females at long range (Bennet-Clark 1989). These calls are characterized by their dominant frequency $(\mathrm{Fd})$, which corresponds to the resonant frequency of the tegminal resonator (Michelsen and Nocke 1974). Fd commonly ranges from 2 to $8 \mathrm{kHz}$ (Leroy 1966) because of physical constraints due to small size (Bennet-Clark 1998) and stridulum functioning (Michelsen and Nocke 1974). However some Eneopterinae crickets are known to call with Fds of 10-15 kHz (Desutter-Grandcolas 1997a), and one

Correspondence to: Tony Robillard

E-mail: robillar@mnhn.fr species (Eneoptera guyanensis) produces a modulated call with both a low and a high Fd (DesutterGrandcolas 1998).

In order to understand $\mathrm{Fd}$ evolution in Eneopterinae, we apply the phylogenetic methodology (Brooks and McLennan 2002) to reconstruct the patterns of evolutionary transformations for their acoustic features (Robillard and DesutterGrandcolas, in prep.). We use a phylogeny reconstructed using morpho-anatomical characters for the whole subfamily (Robillard and Desutter-Grandcolas 2004). Patterns of Fd evolution have been obtained by optimizing Fd states on the phylogeny (Robillard and Desutter-Grandcolas, in prep.). 


\section{MATERIALS AND METHODS}

39 Eneopterinae species and 6 outgroup species were included in the phylogenetic analysis. Ingroup taxa include 2 mute species and 37 acoustic species. Acoustic properties are presently documented for 24 of these 37 species and we demonstrated that they are representative of the acoustic diversity of the whole subfamily (Robillard and DesutterGrandcolas 2004).

Two characters have been defined to describe Fd diversity. The first character (Fda) concerns the frequency corresponding to the vibrations of the usual cricket resonator, i.e. the harp (Michelsen and Nocke 1974). This is a continuous character, which states can be delimited according to natural gaps in the data (Stevens 1991): Fda ranging between 3 and $7.9 \mathrm{kHz}$ (state 0 ), equal to $9.9 \mathrm{kHz}$ (state 1), ranging between 12.2 and $16 \mathrm{kHz}$ (state 2). The second character $(\mathrm{Fdb})$ describes the presence of an additional frequency component resulting from the vibration of another forewing area (Desutter-Grandcolas 1998). This is a binary character corresponding to the presence (state 1) or absence (state 0 ) of an additional frequency.

\section{RESULTS AND DISCUSSION}

The resulting phylogenetic pattern shows that Fda is relatively stable through the whole clade. Ancestrally, Fda ranges from 3 to $7.9 \mathrm{kHz}$ (state 0 ). It has been modified only once, with the occurrence of high $\mathrm{Fd}$ (state 2) in the clade [Cardiodactylus (Lebinthus-Agnotecous)]. High Fd replaces low Fd, resulting in high-frequency calling songs, with a subsequent slight decrease (state $2>$ state 1 ) in one species (Agnotecous sarramea).

This pattern of Fda transformations suggests that Fda evolved abruptly from low to high values. It does not support a hypothesis of progressive change since the only intermediary Fda value (state 1) occurs apically, and not as an intermediary state.

In Eneoptera guyanensis, the pattern of frequency change is different: a high Fdb component is added to the low ancestral Fda, resulting in frequency modulation.

Observation of cladogenesis rates shows that the onset of high Fda in [Cardiodactylus (LebinthusAgnotecous)] is accompanied by a high cladogenesis rate, supporting a hypothesis of adaptive radiation for high-frequency calling (phylogeny criterion of adaptation) (Grandcolas and D'Haese 2003). High Fda could be hypothesized as being a key innovation for an adaptive radiation involving a specialization toward high-frequency calling.

What could be the selective value of highfrequency calling in the natural environment (selection criterion of adaptation; Grandcolas and D'Haese 2003)? High frequencies are particularly problematical for long-range communication (especially for forest-living species) because of the increased attenuation of high frequencies (Marten et al. 1977, Wiley and Richards 1978, Römer 1993).

Species that use high-frequency calling may have evolved behaviors to compensate for the range problems with using high-frequency calls. For example, if Lebinthus and Agnotecous species forage in leaf litter, males perch on high positions while singing (Desutter-Grandcolas 1997b). Perching has been shown to favor song range in various acoustic insects (Forrest 1982, Walker and Whitesell 1982). In the same way, it could represent here a compensatory behavior for high-frequency calling. Other traits of behavioral ecology, like population structure or fine-scale habitats could also compensate the low effective range of these calls by keeping potential receivers in the immediate vicinity of emitting males. High-frequency calls could thus be effective communication signals whatever their acoustic properties.

\section{CONCLUSION}

Fda is relatively stable through the Eneopterinae subfamily. It ancestrally ranges from 3 to $7.9 \mathrm{kHz}$ and has been modified only once, resulting in highfrequency calling. The pattern of transformation of Fda does not support a hypothesis of progressivity; 
instead Fda evolved abruptly from low to high values in [Cardiodactylus (Lebinthus-Agnotecous)], with a subsequent slight decrease in Agnotecous sarramea. Further, in Eneoptera guyanensis, frequency modulation appeared by the addition of a high Fdb component to the low ancestral Fda.

An adaptive radiation for high-frequency calling is hypothesized in [Cardiodactylus (LebinthusAgnotecous)]. Further, it may be associated with compensatory behavior, such as perching, to permit the propagation of high frequencies in the natural environment of the species.

\section{ACKNOWLEDGMENTS}

We thank J. Vielliard and the organizing committee of the XIX IBAC for their invitation, H. Brumm for his comments on the manuscript and A. Ichikawa for sending us digital tapes of Japanese Eneopterinae species. This work was granted by the Muséum national d'Histoire naturelle, Paris.

\section{RESUMO}

A evolução das freqüências dominantes no canto dos grilos Eneopterinae foi estudada em relação à sua filogenia. Dois caracteres são otimizados na árvore filogenética, o primeiro corresponde às freqüências de vibração da harpa (Fda) e o segundo é devido à vibração das outras áreas tegminais (Fdb). Fda mostrou-se ser relativamente estável na sub-família. Seu estado ancestral, de valor baixo, é mudado uma única vez para um valor alto, responsável pelos sons agudos em [Cardiodactylus (LebinthusAgnotecous)]. Um componente agudo Fdb é adicionado ao grave ancestral Fda em Eneoptera guyanensis, produzindo uma modulação de freqüência. O aparecimento de altos valores de Fd neste primeiro grupo é acompanhado por uma taxa alta de cladogênese, o que sustenta a hipótese de radiação adaptativa para altas frequiências sonoras. A eficiência dos sons agudos é discutida em relação à ecologia comportamental das espécies.

Palavras-chave: comunicação acústica, adaptação, cladogênese, Ensifera, padrões evolutivos, filogenia.

\section{REFERENCES}

Bennet-Clark HC. 1989. Songs and the physics of sound production. In: Huber F, MoORE TE AND LOHER W (Eds), Cricket behavior and neurobiology. Ithaca and London: Cornell University Press, p. 227-261.

BenNet-Clark HC. 1998. Size and scale effect as constraints in insect sound communication. Phil Trans R Soc Lond B 353: 407-419.

Brooks DR AND McLennan DA. 2002. The nature of biodiversity: An evolutionary voyage of discovery. Chicago: The University of Chicago Press.

Desutter-Grandcolas L. 1997a. Les grillons de Nouvelle-Calédonie (Orthoptères, Grylloidea): espèces et données nouvelles. In: NAJT J AND MATILE L (Eds), Zoologia Neocaledonica 4. Paris: Mém Mus Natl Hist nat 171, p. 165-177.

Desutter-Grandcolas L. 1997b. Le peuplement de grillons (Orthoptères, Grylloidea) des sous-bois forestiers du Col d'Amieu (Nouvelle-Calédonie). I Etude du peuplement. In: NAJt J AND Matile L (Eds), Zoologia Neocaledonica 4. Paris: Mém Mus Natl Hist nat 171, p. 125-135.

Desutter-Grandcolas L. 1998. Broad-frequency modulation in cricket (Orthoptera, Grylloidea) calling songs: two convergent cases and a functional hypothesis. Can J Zool 76: 2148-2163.

ForRest TG. 1982. Acoustic communication and baffling behaviors in crickets. The Florida Entomologist 65: 33-44.

Grandcolas P and D'Haese C. 2003. Testing adaptation with phylogeny: how to account for phylogenetic pattern and selective value together? Zool Scr 32: 483-490.

LEROY Y. 1966. Signaux acoustiques, comportement et systématique de quelques espèces de Gryllides (Orthoptères, Ensifères). Bull Biol Fr Belg 100: 1-134.

Marten K, Quine D and Marler P. 1977. Sound transmission and its significance for animal vocalization. II. Tropical forest habitats. Behav Ecol Sociobiol 2: 291-302.

Michelsen A And Nocke H. 1974. Biophysical aspects of sound communication in insects. Adv Insect Physiol 10: 247-296. 
Robillard T AND Desutter-Grandcolas L. 2004. Phylogeny and the modalities of acoustic diversification in extant Eneopterinae crickets (Insecta, Orthoptera, Grylloidea, Eneopteridae). Cladistics: in press.

RöMER H. 1993. Environmental and biological constraints for the evolution of long-range signalling and hearing in acoustic insects. Phil Trans R Soc Lond B 340: 179-185.

Stevens PF. 1991. Character states, morphological variation, and phylogenetic analysis: a review. Syst Bot 16: $553-583$.
Walker TJ AND Whitesell J. 1982. Singing schedules and sites for a tropical burrowing cricket (Anurogryllus muticus). Biotropica 14: 220-227.

Wiley RH AND RichaRds DG. 1978. Physical constraints on acoustic communication in the atmosphere: Implications for the evolution of animal vocalizations. Behav Ecol Sociobiol 3: 69-94. 